\title{
Comb, cloaca and feet scores and testis morphometry in male broiler breeders at two different ages
}

\author{
[Escores de crista, cloaca e de pé e morfometria testicular em galos de matriz \\ pesada em duas diferentes idades] \\ R.A.C. Leão ${ }^{1}$, F.L.S. Castro ${ }^{1}$, P.R. Xavier ${ }^{1}$, D.P. Vaz ${ }^{1}$, J.G.V. Grázia ${ }^{1}$, N.C. Baião ${ }^{2}$, \\ G.F. Avelar ${ }^{3}$, A.P. Marques Júnior ${ }^{2}$
${ }^{1}$ Aluno de pós-graduação - Escola de Veterinária - Universidade Federal de Minas Gerais - Belo Horizonte, MG
${ }^{2}$ Escola de Veterinária - Universidade Federal de Minas Gerais - Belo Horizonte, MG
${ }^{3}$ Instituto de Ciências Biológicas - Universidade Federal de Minas Gerais - Belo Horizonte, MG

\begin{abstract}
In broiler breeder roosters, the weight of the testes is positively associated with daily sperm production and fertility. In birds, the testes are located in the coelomic cavity, not being accessible to reproductive evaluation as mammalian testes. The reproductive evaluation of roosters is based on phenotypic traits. Any changes on testes will be reflected on fertility levels. The aim of this paper was to evaluate the potential of association of phenotypic traits as body weight (BW), comb scores (COS), cloaca scores (CLS) and feet scores (FS) with testicular morphometric parameters in adult $\mathrm{Cobb}{ }^{\circledR} \mathrm{Mx}$ roosters in two ages ( 25 and 45 weeks of age). The low BW roosters had lower testes weight (TW), smaller seminiferous tubule diameter (STD) and lower comb and cloaca scores than the medium and high BW roosters $(\mathrm{P} \leq 0.05)$. Heavy roosters had the highest COS and bigger seminiferous epithelium height (SEH). There was no statistical difference between the BW categories in FS and volumetric proportion of seminiferous tubule (ST) and interstitial tissue (IT). Considering the age effect, roosters with 45 weeks of age had lower TW and ST than 25-week roosters. Positive, moderate and significant correlation was found between testes weight and phenotypic characteristics as BW, COS and CLS in 45week roosters. A positive, moderate and significant correlation was found between body weight and histologic testicular characteristics as STD and SHE in both evaluated ages. In conclusion, there is a regression in the testes weight with age and it is more intense in $\mathrm{Cobb}{ }^{\circledR} \mathrm{Mx}$ roosters with lower BW. Furthermore, it is concluded that the BW positively influences the testes weight and histological quality of the testes. COS and CLS can be used with moderate potential prediction to identify roosters with low testes weight at 45 weeks of age.
\end{abstract}

Keywords: testicular regression, rooster, histomorphometry, phenotypic characteristics, histology

\section{RESUMO}

Em galos de matriz pesada sabe-se que o peso dos testículos pode ser associado positivamente com a produção diária de espermatozoides e que alterações nos testículos irão refletir na fertilidade. Nas aves, os testículos estão localizados dentro da cavidade celomática, e, portanto, não são acessíveis para exame andrológico direto, como em mamíferos. A avaliação reprodutiva de galos se baseia principalmente em características fenotípicas. Buscou-se avaliar o potencial de associação de alguns parâmetros fenotípicos, como peso corporal (PC), escores de crista (ECR), escores de cloaca (ECL) e escores de pés (EP), com parâmetros morfológicos de testículos em galos Cobb® Mx em duas idades (25 e 45 semanas de idade). Galos leves apresentaram menor peso testicular (PT), menor diâmetro de túbulo seminífero (DT), e menores ECR $e$ ECL que galos médios e pesados $(P \leq 0.05)$. Galos pesados apresentaram os maiores ECR e maiores valores para altura do epitélio seminífero (AE), e DT. Não houve diferença estatisticamente significativa entre as categorias de peso para escores de pé e proporções de túbulo seminífero (TS) e interstício (INT). Considerando-se o efeito da idade, galos com 45 semanas de idade apresentaram menores PT e TS que galos com 25 semanas de idade. Correlação positiva, moderada e significativa foi encontrada entre peso de testículo e características fenotípicas como ECR, ECL e PC em galos de 45 semanas de idade. Foi encontrada

Recebido em 9 de junho de 2016

Aceito em 5 de janeiro de 2017

E-mail: rafaelleao@ufmg.br 
correlação positiva, moderada e significativa entre PC e características testiculares como DT e AE nas duas idades avaliadas. Conclui-se que em galos Cobb ${ }^{\circledR}$ Mx ocorre regressão do testículo com o avanço da idade, $e$ ela é mais intensa em galos com menor peso corporal. Conclui-se que o PC tem influência positiva no peso e indices histomorfométricos dos testículos, e que escores de crista e de cloaca podem ser utilizados com potencial moderado de predição para identificar galos com baixo peso de testículos em galos com 45 semanas de idade.

Palavras-chave: crista, cloaca, testículo, histomorfometria, regressão testicular

The genetic selection on broiler breeder lineages (Gallus gallus domesticus) has been focused on the production of broiler chickens capable of achieving better slaughter weight ratios, carcass yield, and increased breast and thigh, with reduced feed conversion rate (Vizcarra et al. 2010). However, this success seen in the production is contrasted with a sharp drop in fertility after 45 weeks of age, usually related to males (Fragoso et al., 2013). As in other species, in the domestic rooster, testes weight has a positive association with daily sperm production and fertility. There is a relationship between testicular morphology and semen quality and production, consequently, changes in the rooster's gonads will be reflected on fertility (Hocking and Bernard, 1997; Kirby et al., 1998). In birds, the testes are located within the coelomic cavity, and thus cannot be directly examined through andrologic evaluation, as in mammals. Because of the difficulty of conditioning these animals for semen collection imposed by the creation in sheds, evaluation of semen parameters and individual fertility is not made in this species under commercial production conditions (Amann, 1999). Alternative reproductive assessment methods have been proposed for the selection of genetically superior roosters in order to improve fertility. Among them, the use of testicular ultrasound can be observed, withdrawing squad cocks which have characteristics that might lead to sexual incompetence, for example, excess or deficiency of body weight; problems associated with the legs and the feet; and evaluation of phenotypic features suggestive of subfertility such as low quality comb, or small, pale and dry cloaca (Amann, 1999; McGary et al., 2002; Rezende et al., 2014). Body weight is known to have an association with testes weight and, in 71week roosters, cloaca and comb scores can be used with moderate potential prediction to identify low testes weight (Rezende et al., 2014). In order to better understand the current reproductive profile of broiler breeder roosters and to increase reproductive efficiency in commercial batches by selecting reproductively superior roosters, it is necessary to monitor their reproductive status in different stages of life. Thus, the aim of this study was to evaluate subjectively phenotypic characteristics used commercially as selection criteria in broiler breeder roosters and to associate them with reproductive parameters as testes weight and morphometry during two stages: puberty and adulthood.

\section{MATERIAL AND METHODS}

The project was approved by the Ethics Committee in Animal Experimentation (CEUA) UFMG (Protocol .79 / 2015). The experimental design was completely randomized in a $2 \times 3$ factorial arrangement: two ages (25 weeks and 45 weeks) and three bodyweight categories (light, medium or heavy) with 10 replicates each, and the experimental unit consisted of one animal. Cobb® Mx male and female one day old chicks were bred in a conventional manner, separately until 22 weeks of age, respecting stocking density, lighting and temperature recommended by the lineage guide, subjected to feed restriction and ad libitum water. At 22 weeks of age, which is considered as the production phase, males and females began to be raised together in the ratio of one male for each 10 females. Throughout the entire production period, the animals received 14 continuous hours of light per day, regardless of the natural photoperiod. In the months when the days were shorter, the daylight period was complemented and preceded by artificial light. The roosters were evaluated at two ages: 25 weeks of age $(n=$ 30) considered as the beginning of reproductive period and 45 weeks of age $(n=30)$ considered as adulthood. In each evaluated age, a random sample of about $3 \%$ of the shed cocks was weighed. From this data, three body weight categories were established. The weight values \pm $10 \%$ of the sample weight average were 
considered borderline between heavy / medium and medium / light categories, according to the methodology used by Rezende et al. (2014). After weighing and establishment of body weight categories, all roosters were inspected by a single trained evaluator, to evaluate the comb and cloaca morphology and the presence of lesions in the feet. Thus, comb, cloaca, and feet scores were established following the same methodology described by Rezende et al. (2014). After phenotypic evaluations and scores determination, the roosters were identified, separated and slaughtered following the standards of humane slaughtering. Then, the testes were removed, individually weighed in digital analytical balance, and placed in Karnovsky fixative solution (4\% paraformaldehyde and $2.5 \%$ glutaraldehyde in $0.2 \mathrm{M}$ sodium phosphate buffer $\mathrm{pH}$ 7.2) for histological processing. The tissue was dehydrated through a graded series of ethanol, embedded in methacrylate resin (Historesin, glycol methacrylate, Leica $\left.{ }^{\circledR}\right)$ cut into $3 \mu \mathrm{m}$ thick sections and then the slides were stained with Toluidine blue solution. Digital images of histological fields were obtained using the software cell $\wedge \mathrm{F}$ and analyses were done with ImageJ v1.50f software. The tubular diameter, the seminiferous epithelial height; and the volumetric proportion of tubules and interstitial area were measured. The average tubular diameter per animal was obtained from the measurement of 20 randomly obtained crosssections of circular seminiferous tubules per animal in 200x magnification. Two perpendicular measures in each field (Figure 1) were performed, and the arithmetic mean of these values was used for statistical analysis. The same images used for measuring diameters were used to measure the seminiferous epithelium height. From the measurement of the smallest diameter, two epithelial height measurements were taken from the basement membrane to the tubule lumen (Figure 1). The arithmetic mean of these values was used for statistical analysis.

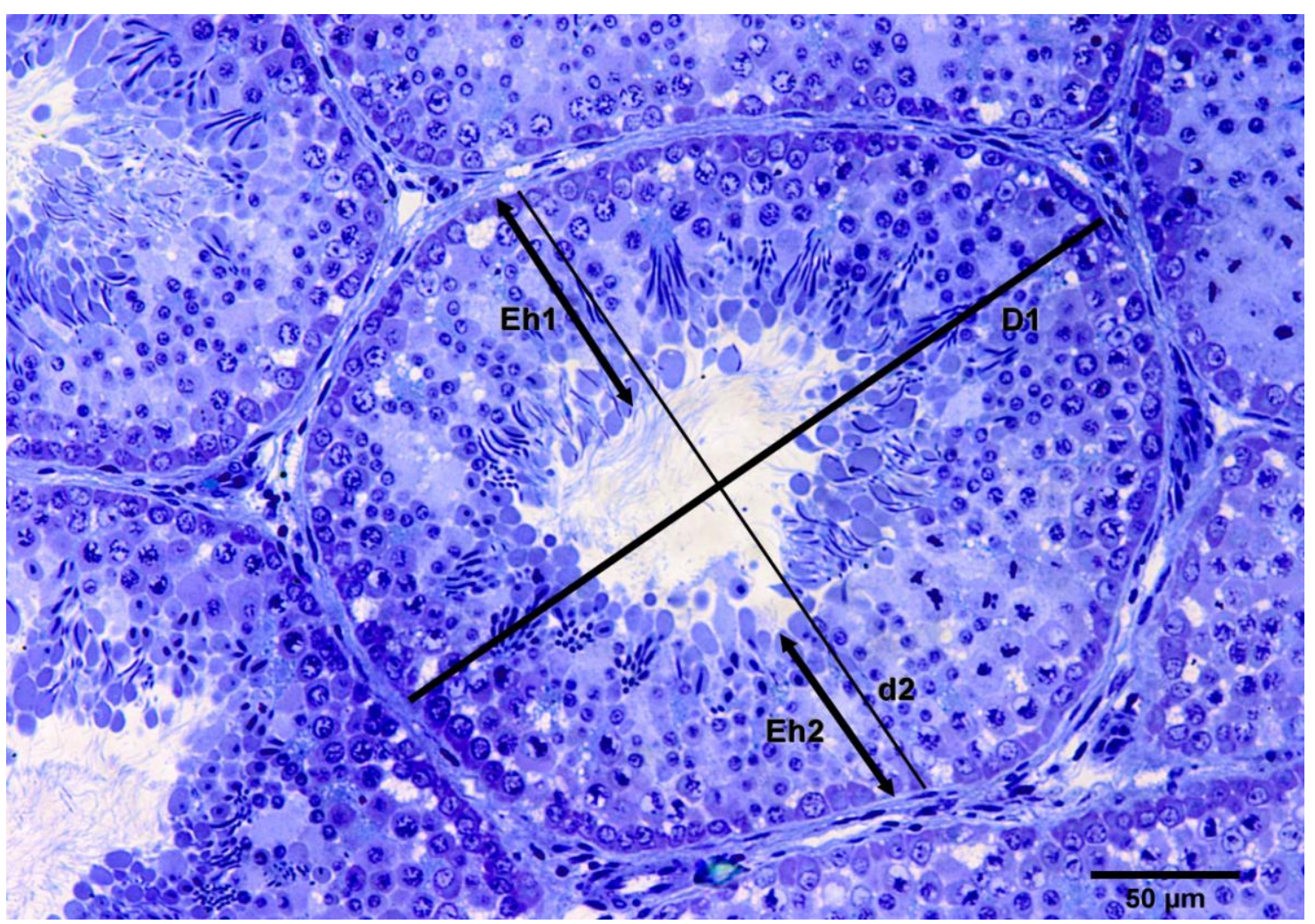

Figure 1. Rooster. Seminiferous tubule in cross section. Photography outline the greatest diameter measurements (D1), smaller diameter (d2) and seminiferous epithelium heights (Eh1 and Eh2). Light bodyweight rooster with 45 weeks of age (200x, Toluidine Blue). 
To study the volumetric proportion of seminiferous tubule (ST) and interstitial tissue (IT), 10 random fields were used at $200 x$ magnification on which a 475 equidistant intersections grade was overlaid. All points were accounted in accordance with the structure they were overlapping (Figure 2). The sum of the incident points in each of the structures was evaluated, divided by 4,750 and multiplied by 100 to obtain the volumetric proportion. As the testes density is around one, the mass of testes was considered equal to its volume (Franca et al., 2003).

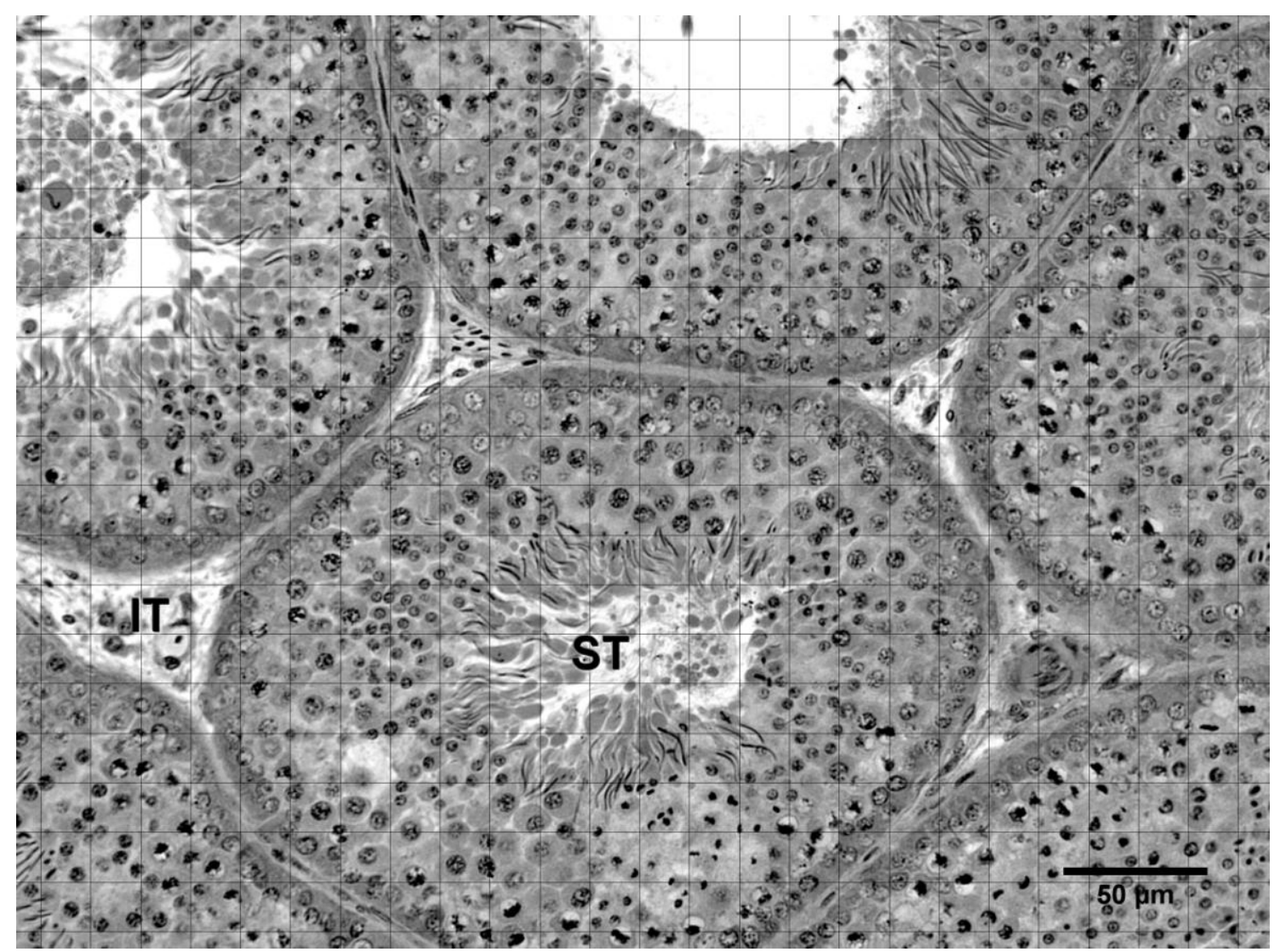

Figure 2. Rooster. 475 equidistant point grid overlaying testes cross section showing seminiferous tubules (ST) and interstitial tissue (IT). Heavy bodyweight rooster with 25 weeks of age. (200x, Toluidine Blue).

Statistical analyzes were performed using SAS (2002) with a significance level of $5 \%(\mathrm{p} \leq 0.05)$. Normal data and homogeneous variances were subjected to analysis of variance (ANOVA) and the means were compared by Tukey test (coefficient of variation lower than 10\%) or Duncan (coefficient of variation greater than $10 \%$ ). For variables with non-normal distribution, such as the comb scores (COS), cloaca scores (CLS) and feet scores (FS), comparisons of ages were performed using the Mann \& Whitney test and comparisons of weight groups were done using the Kruskal-Wallis test, and in case of significance were compared two by two using the Mann \& Whitney test. To study the correlations between the normal distribution variables, the Pearson correlation was used. For correlations between scores: COS, CLS, FS, and those with other characteristics, the Spearman correlation was used.

\section{RESULTS AND DISCUSSION}

The results of average body weight (BW), right testes weight (RTW), left testes weight (LTW), the total testes weight (TW) and gonadossomatic index (GI) are showed in Table 1. 
Table 1. Average body weight (BW), right testes weight (RTW), left testes weight (LTW), the total testes weight $(\mathrm{TW})$ and gonadossomatic index (GI) of $\mathrm{Cobb} \mathrm{Mx}{ }^{\circledR}$ roosters according to age and bodyweight category

\begin{tabular}{cccccc}
\hline & \multicolumn{5}{c}{ Variable } \\
\cline { 2 - 6 } Categories & BW $(\mathrm{g})^{1}$ & RTW $(\mathrm{g})^{2}$ & LTW $(\mathrm{g})^{2}$ & TW $(\mathrm{g})^{2}$ & GI $^{2}$ \\
\hline Age & & & & \\
25 & $3917.33 \mathrm{~b}$ & $14.16 \mathrm{a}$ & $16.19 \mathrm{a}$ & $30.49 \mathrm{a}$ & $0.781 \mathbf{a}$ \\
45 & $4674.67 \mathrm{a}$ & $9.62 \mathrm{~b}$ & $11.39 \mathrm{~b}$ & $20.1 \mathrm{~b}$ & $0.443 \mathbf{b}$ \\
\hline Bodyweight & $3606 \mathrm{c}$ & $9.81 \mathrm{~b}$ & $10.97 \mathrm{~b}$ & $20.76 \mathrm{~b}$ & 0.588 \\
Light & $4270.5 \mathrm{~b}$ & $12.38 \mathrm{a}$ & $14.17 \mathrm{a}$ & $26.54 \mathrm{a}$ & 0.597 \\
Medium & $5011.5 \mathrm{a}$ & $13.48 \mathrm{a}$ & $15.97 \mathrm{a}$ & $29.45 \mathrm{a}$ & 0.640 \\
Heavy & & & & $<.0001^{*}$ \\
Anova effect & $<0.0001^{*}$ & $<0.0001^{*}$ & $<0.0001^{*}$ & $<0.0001^{*}$ & $0.5457^{\text {ns }}$ \\
Age (A) & $<0.0001^{*}$ & $0.0010^{*}$ & $0.0001^{*}$ & $0.0003^{*}$ & $0.0136^{*}$ \\
Weight (W) & $0.1905^{\text {ns }}$ & $0.2532^{\mathrm{ns}}$ & $0.0637^{\text {ns }}$ & $0.1103^{\text {ns }}$ & 23 \\
Interaction AxW & 5.3 & 25.3 & 23.92 & 23.86 & 23
\end{tabular}

${ }^{1}$ Means followed by different letters differ by Tukey test $(\mathrm{P} \leq 0.05)$.

${ }^{2}$ Means followed by different letters differ by Duncan test $(\mathrm{P} \leq 0.05)$.

$\mathrm{ns}=$ not significant by $\mathrm{F}$ test $(\mathrm{p}>0.05) .{ }^{*}$ significant by $\mathrm{F}$ test $(\mathrm{P} \leq 0.05)$

$\mathrm{CV}=$ coeficient of variation.

There was no interaction between age and weight (AxW) for BW, RTW, LTW, and TW variables. There was a significant effect of age and bodyweight categories $(p \leq 0.05)$ in these variables. On average, Cobb $\mathrm{Mx}^{\circledR}$ roosters at 25 weeks of age were lighter $(3.917 \mathrm{~kg})$ than roosters with 45 weeks $(4.675 \mathrm{~kg})(\mathrm{p} \leq 0.05)$, which was expected since the BW is a trait that increases with age (Hocking and Bernard, 1997). As expected, there was a significant difference $(p \leq 0.05)$ between roosters of different bodyweight categories: light $(3.606 \mathrm{~kg})$, medium $(4.271 \mathrm{~kg})$ and heavy $(5.012 \mathrm{~kg})$. The low coefficient of variation for $\mathrm{BW}(\mathrm{CV}=5.3 \%)$ shows good uniformity of the males (Tab. 1). Roosters at 25 weeks of age showed higher RTW, LTW and TW than 45 week roosters $(p \leq 0.05)$. A physiological characteristic of birds is the decline in testicular weight after a period of fertility. The exact timing of this event may vary, since it is influenced by several factors such as photoperiod, age, lineage and nutritional management (Tyler and Gous 2009; Fragoso et al., 2013; Lara, 2015). Considering the results, testicular regression is speculated to have already occurred in 45 weeks old $\mathrm{Cobb} \mathrm{Mx}^{\circledR}$ roosters. Fragoso et al. (2013), studying Cobb $500^{\circledR}$ Slow roosters observed that up to $44 \%$ of testicular weight could be lost between 36 and 55 weeks of age. In this study, decrease of $31 \%$ in this trait between 25 and 45 weeks old was observed. In a research done by Young et al. (2001), the authors noted that in seasonal birds, regression of the testes resulted from seminiferous epithelium atrophy caused primarily by apoptosis of Sertoli cells and degeneration of spermatogenic lineage cells after negative photoperiod season. In the current experiment, the animals received the same amount of light throughout the production period, using complementation with artificial light in short periods of days. However, it is speculated that artificial light does not have the same effectiveness as the natural light at the stimulation of neuroendocrine mechanisms that maintain testicular development, since regression of the testes in roosters with 45 weeks of age that were living in a period of negative photoperiod with supplementation with artificial light was observed. Light bodyweight roosters had lower LTW, RTW and TW than those in medium and heavy categories $(\mathrm{P} \leq 0.05)$. Sexton et al. (1989) showed that Ross roosters subjected to severe energy restriction, obtained body weight lower to $4.00 \mathrm{~kg}$ at 52 weeks of age and stopped ejaculating or ejaculated semen with low concentration of sperm. Light roosters in a hierarchical scale, suffer more attacks and eat less. It is possible that roosters in this category may have suffered a more severe food restriction and that, associated with higher serum cortisol concentrations, have resulted in a sharper regression in testicular weight. The results for comb scores (COS), cloaca scores (CLS) and feet scores (FS) are shown in Table 2. 
Table 2. Comb scores (COS), Cloaca scores (CLS) and Feet scores (FS) of Cobb Mx ${ }^{\circledR}$ roosters according to age and bodyweight category

\begin{tabular}{cccc}
\hline & \multicolumn{3}{l}{ Variables } \\
Categories & COS (1 to 4) & CLS (3 to 8) & FS (0 to 6) \\
\hline Age & & & \\
25 & 2.93 & $5.43 \mathrm{~b}$ & $0.50 \mathrm{~b}$ \\
45 & 2.90 & $6.17 \mathrm{a}$ & $2.53 \mathrm{a}$ \\
\hline Bodyweight & & $5.15 \mathrm{~b}$ & 1.30 \\
Light & $2.35 \mathrm{c}$ & $6.10 \mathrm{a}$ & 1.15 \\
Medium & $2.90 \mathrm{~b}$ & $6.15 \mathrm{a}$ & 2.10 \\
Heavy & $3.50 \mathrm{a}$ & & $<0.0001^{*}$ \\
Anova effect & & $0.0218^{*}$ & $0.0955^{\text {ns }}$ \\
Age (A) & $0.9496^{\mathrm{ns}}$ & $0.0261^{*}$ & \\
Weight (W) & $<0.0001^{*}$ & & \\
\hline
\end{tabular}

$\mathrm{ns}=$ not significant by the Kruskal-Wallis test $(\mathrm{P}>0.05)$.

* = significant by the Kruskal-Wallis test $(\mathrm{P} \leq 0.05)$.

There was no statistical difference for COS between roosters with 25 and 45 weeks old. The effect of bodyweight can be observed, since heavy roosters were those with the highest COS, and light roosters the lowest. It is known that testosterone and dihydrotestosterone influence the growth of comb and dewlap because it stimulates the production of intracellular fluid by fibroblasts in these locations. Testicular weight is known to have a positive association with the production of testosterone (Hardesty 1939, mentioned by Navara et al., 2012). In the current experiment, positive, moderate, and significant correlation was found between $\operatorname{COS}$ and $\mathrm{BW}$ (Table 3). Moderate and positive correlation was also found between COS and TW. These results suggest that heavier roosters have larger testes and consequently more androgen production capacity that will influence the highest COS. A similar result was obtained by Rezende et al. (2014) for both associations. Positive, moderate, and significant correlation was found between COS and diameter of seminiferous tubule for both of the ages, and between COS and seminiferous epithelium height in 45-week roosters. These findings suggest that the comb score, used in the current experiment, can be used with moderate potential prediction for selection of roosters with histological features consistent with higher sperm production. Figure 3 shows examples of comb morphology in four Cobb $\mathrm{Mx}^{\circledR}$ roosters and their classifications in scores.

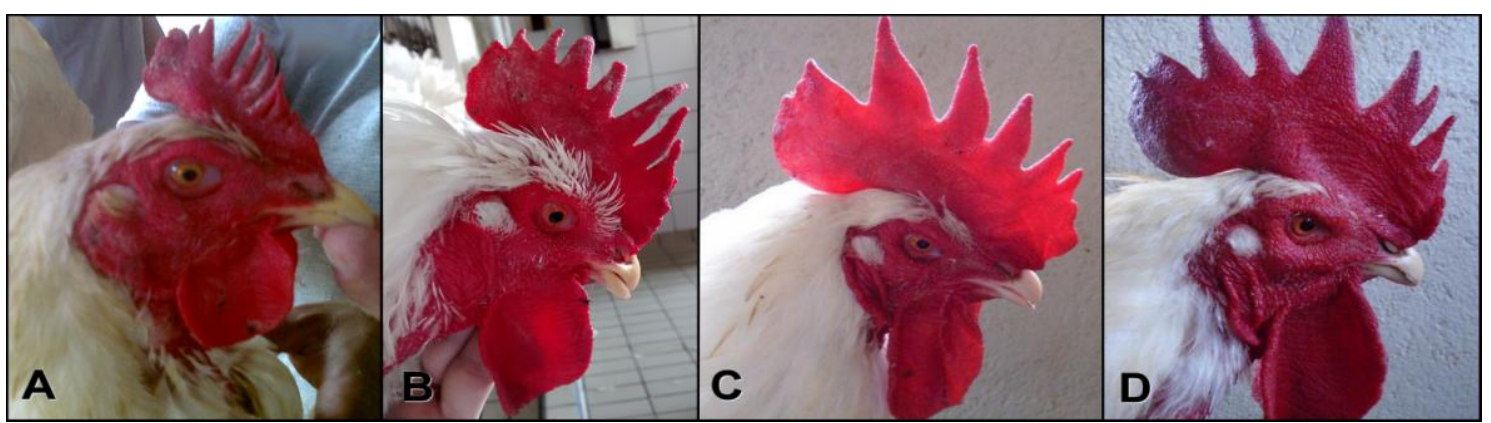

Figure 3. Rooster. Comb Scores. (A) Comb score = 1, undeveloped comb. (B) Comb score = 2, average comb, light red and turgid. (C) Comb score $=3$, large comb, intense red and turgid. (D) Comb score $=4$, very large comb, intense red and turgid. 
Table 3. Pearson and Spearman correlations between body weight (BW); testes weight (TW); seminiferous tubule diameter (TD); seminiferous epithelium height (SEH); proportions of seminiferous tubules (ST), proportion of interstitial tissue (IT) and comb scores (COS), cloaca scores (CLS) and feet scores (FS) in Cobb Mx ${ }^{\circledR}$ roosters

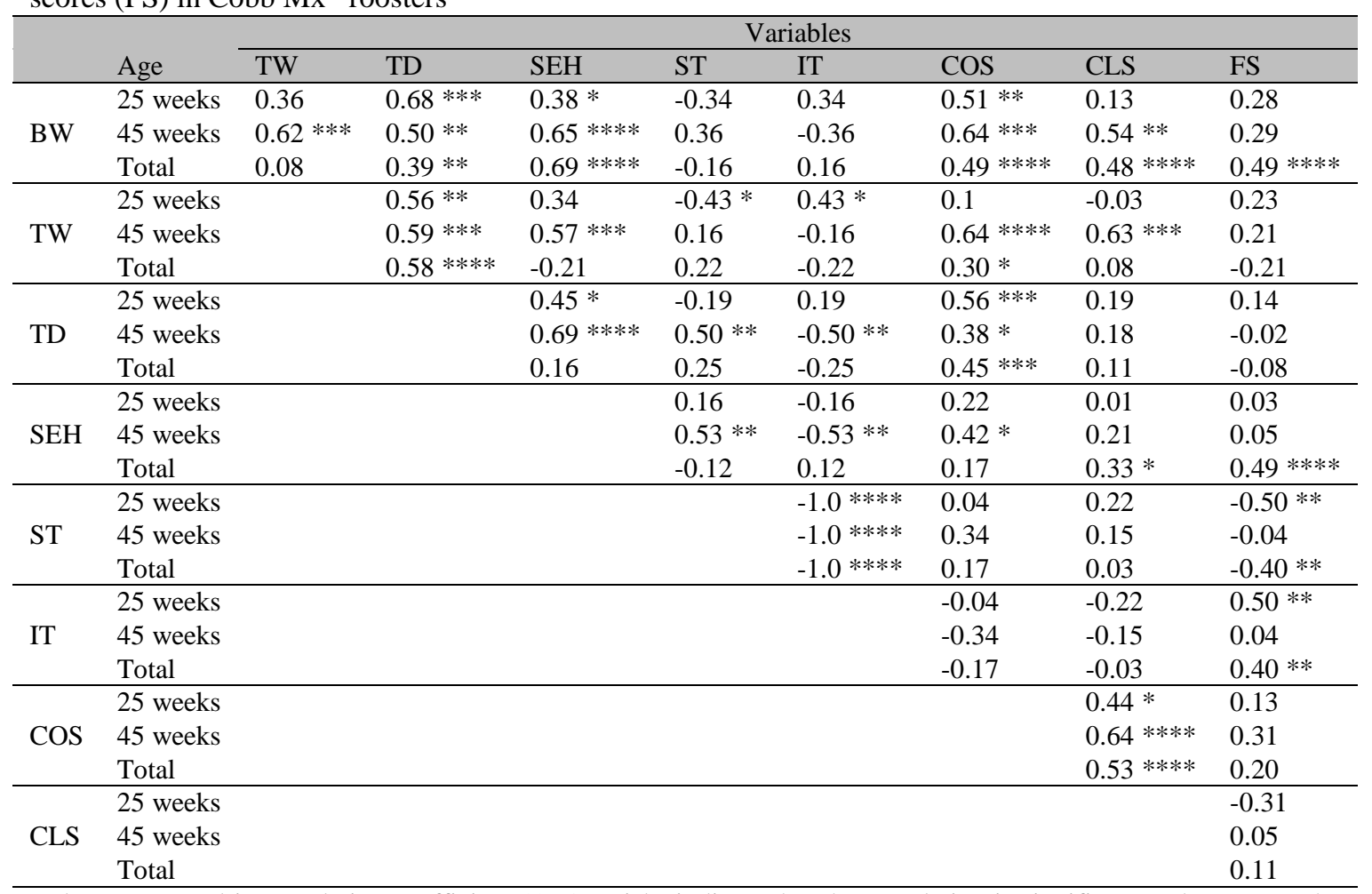

Values expressed in correlation coefficient (r). Asterisks indicate that the correlation is significant and represent the significance level: $\mathrm{P} \leq 0.05(*), \mathrm{P} \leq 0.01(* *), \mathrm{P} \leq 0.001(* * *)$ and $\mathrm{P} \leq 0.0001(* * * *)$. TD, SEH, ST and IT parameters were evaluated in the left testicle. Associations between normal distribution characteristics were studied by Pearson correlation. Associations between the COS, CLS, FS, and those with other characteristics were studied by Spearman correlation.

Adult roosters have higher cloaca scores than young cocks $(\mathrm{p} \leq 0.05)$. In the current experiment, CLS was established from the visual inspection of three different characteristics of the cloaca: size, color and humidity. Studies are needed to assess whether the interference in the CLS is androgen-dependent, if it is associated with increased sexual activity or both effects influence the size, color and humidity from the cloaca. Moderate and positive correlation was observed between CLS and seminiferous epithelium height (Table 3), suggesting that roosters with the highest cloaca scores have higher germline cells proliferation. There was influence of the weight categories in this variable, and roosters of medium and heavy categories showed higher CLS than the lightweight roosters $(\mathrm{P} \leq 0.05)$. Fantini (2007) observed that roosters subjected to five to seven fasting days decreased, respectively, $6.7 \%$ and $15.6 \%$ of the cloaca diameter. During the production, broiler breeder roosters live in constant food restriction. Within a hierarchical scale, light roosters are those who have less access to food. Possibly, a longer time in fasting may have influenced the smaller size of the cloaca, resulting in lower CLS in lighter roosters. Figure 4 shows examples of cloacal morphology in four Cobb $\mathrm{Mx}^{\circledR}$ roosters and their classifications in scores. 


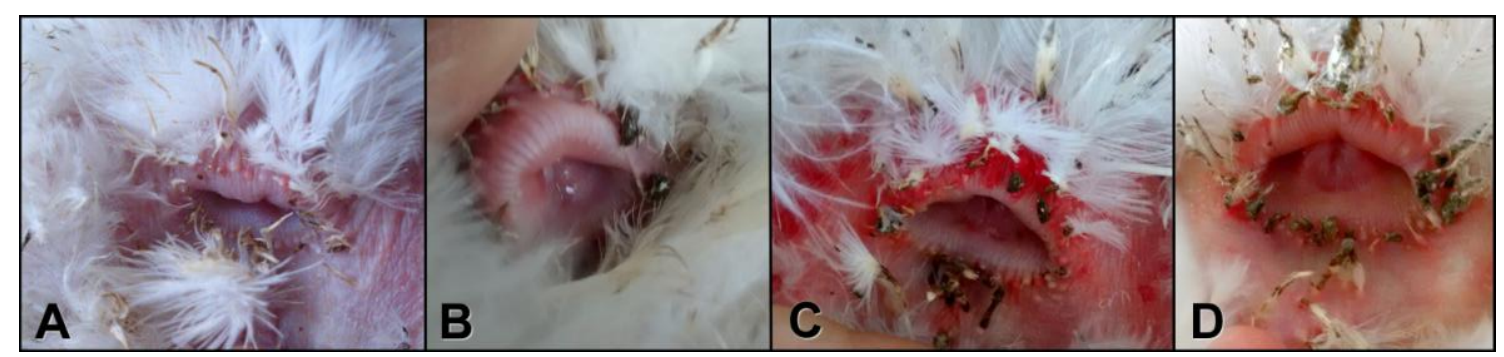

Figure 4. Rooster. Cloaca Scores. (A) Cloaca score $=4$ average cloaca, pale and dry. (B) Cloaca score $=5$, small cloaca, light red and wet. (C) Cloaca score $=6$, great cloaca, light red and dry. (D) Cloaca score $=8$, great cloaca, intense red and wet.

Forty-five-weeks-old rooster have shown higher FS than 25-week-roosters $(\mathrm{P} \leq 0.05)$. This result was expected, since the litter conditions in which the roosters live directly interfere with the appearance of foot lesions and plantar injuries (Ross, 2013). Over time, the quality of the litter tends to get worse, since there is an increase of the humidity accumulated and increased fermentation, which predispose animals to greater foot problems such as pad lesions. The control and reduction of litter humidity reduce footpad injuries of roosters, and this can positively influence copulation capacity of these birds (Lara, 2015). There was no weight effect for FS. However, the association study between these traits showed that there is a positive, moderate and significant correlation between FS and body weight (Table 3). This confirms the hypothesis that, although there are higher testicular weights (Table 1) and histologic traits consistent with higher sperm production capacity as tubule diameter and seminiferous epithelium height (Table 4), roosters with higher body weight tend to have higher number of injuries in the footpad. However, a behavioral study would be necessary to determine whether these injuries influenced negatively the amount of copulation, which was not done in this experiment. In Figure 5 there are examples of presence and intensity of callus on the feet in four Cobb $\mathrm{Mx}^{\circledR}$ roosters and their classifications in scores.

The results obtained for seminiferous tubule diameter (TD), seminiferous epithelium height $(\mathrm{SEH})$, volumetric proportion of seminiferous tubules (ST) and the proportion of interstitial tissue (IT) are showed in Table 4.

There was no interaction (AxW) between categories for the variables TD and SEH. For the $\mathrm{SEH}$ variable there was effect of age and bodyweight categories $(\mathrm{P} \leq 0.05)$. According to Etches (1996), the spermatogenic activity measured by cell proliferation is determined by the increase in the diameter of the seminiferous tubules and height of the seminiferous epithelium. Adult roosters showed higher SEH than young $(\mathrm{P} \leq 0.05)$. This result indicates that roosters with 45 weeks of age showed greater proliferation of the seminiferous epithelium than 25-week-roosters. These data could be interpreted as sexual immaturity of roosters at 25 weeks of age, however, with the assessment of histological slides, all the roosters at that age had apparently normal spermatogenesis. With regard to weight categories, heavy roosters had higher SEH than medium and light roosters and positive, moderate and significant correlation was found between body weight and SEH (Table 3 ). It is also observed that heavy roosters were also those who had higher testes weights (Table 1). Vizcarra et al. (2010) found a strong correlation between testes weight and FSH, hormone associated with the proliferation of Sertoli cells, important in the development of spermatogenesis. It is speculated that heavy roosters have a higher concentration of circulating gonadotropins, which directly influences the proliferation of spermatogenic germ cell line, leading to increased epithelial height. With increasing age, it can be seen that the lightweight roosters suffer reduction in the proportion of ST and thus increase the proportion of IT $(\mathrm{P} \leq 0.05)$. Light roosters also presented lower TW, TD and SEH, indicating that testicular regression in this category is more intense. This regression appears to be primarily caused by the decrease in the proportion of ST in relation IT, since there was a reduction of $4.4 \%$ in the proportion of ST in light roosters whereas in medium and heavy this decrease was $1.8 \%$ and $0.2 \%$, respectively. Based on SEH, TD, IT 
and ST data, there was an indication that the low body weight has a negative influence on reproduction and lightweight roosters suffer more severe ageing testicular regression between the three weight categories evaluated.

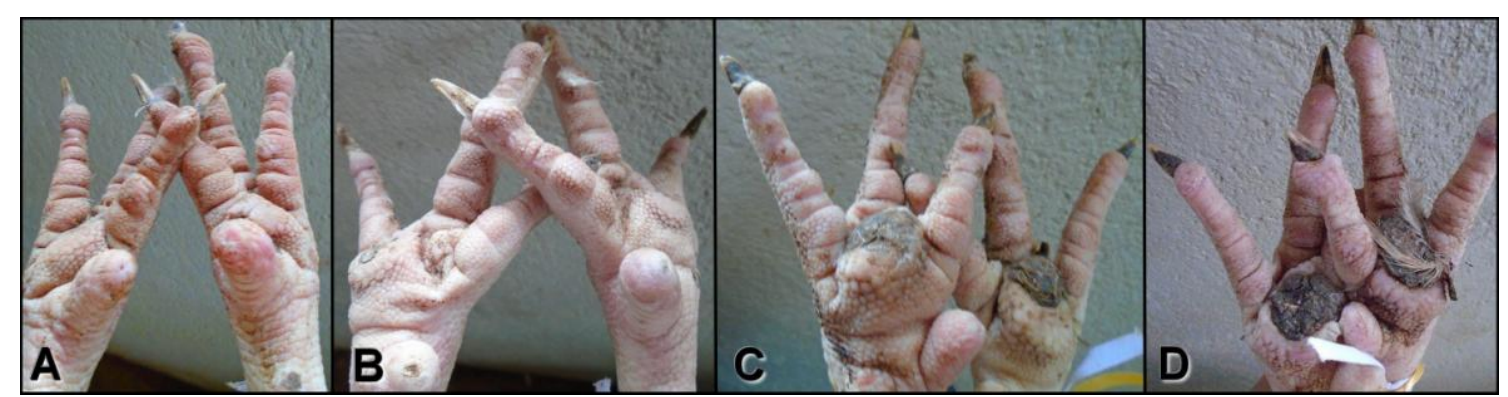

Figure 5. Rooster. Feet Scores. (A) Feet score $=0$, absence of callus. (B) Feet score $=1$, light callus on one foot. (C) Feet score $=4$, moderate callus on both feet. (D) Feet score $=6$, intense callus on both feet.

Table 4. Seminiferous tubule diameter (TD), seminiferous epithelium height (SEH), volumetric proportion of seminiferous tubules (ST) and the proportion of interstitial tissue (IT) of Cobb $\mathrm{Mx}^{\circledR}$ roosters according to age and bodyweight category

\begin{tabular}{|c|c|c|c|c|}
\hline \multirow[b]{2}{*}{ Categories } & \multirow[b]{2}{*}{$\mathrm{TD}(\mu \mathrm{m})^{1}$} & \multicolumn{3}{|c|}{ Variables } \\
\hline & & SEH $(\mu \mathrm{m})^{1}$ & $\mathrm{ST}(\%)^{1}$ & $\operatorname{IT}(\%)^{2}$ \\
\hline \multicolumn{5}{|l|}{ Age } \\
\hline 25 & 274.49 & $95.02 b$ & $92.67 \mathrm{a}$ & $7.33 b$ \\
\hline 45 & 263.74 & $127.36 \mathrm{a}$ & $90.70 \mathrm{~b}$ & $9.3 \mathrm{a}$ \\
\hline \multicolumn{5}{|l|}{ Bodyweight } \\
\hline Light & $249.33 b$ & $105.13 b$ & 91.43 & 8.57 \\
\hline Medium & $271.48 \mathrm{a}$ & $108.48 b$ & 91.73 & 8.27 \\
\hline Heavy & $286.55 \mathrm{a}$ & $119.98 \mathrm{a}$ & 91.9 & 8.10 \\
\hline \multicolumn{5}{|l|}{ Anova effect } \\
\hline Age (A) & $0.0615^{\mathrm{ns}}$ & $<0.0001 *$ & $0.0006^{*}$ & $0.0006 *$ \\
\hline Weight (W) & $<0.0001 *$ & $<0.0001 *$ & $0.7718^{\mathrm{ns}}$ & $0.7718^{\mathrm{ns}}$ \\
\hline Interaction $\mathrm{AxW}$ & $0.5282^{\mathrm{ns}}$ & $0.1399^{\mathrm{ns}}$ & $0.0146 *$ & $0.0146^{*}$ \\
\hline $\mathrm{CV}(\%)$ & 8.10 & 9.09 & 2.27 & 25.01 \\
\hline
\end{tabular}

${ }^{1}$ Means followed by different letters differ by Tukey test $(\mathrm{p} \leq 0.05)$.

${ }^{2}$ Means followed by different letters differ by Duncan test $(\mathrm{p} \leq 0.05)$.

$\mathrm{ns}=$ not significant by $\mathrm{F}$ test $(\mathrm{p}>0.05) .{ }^{*}$ significant by $\mathrm{F}$ test $(\mathrm{p} \leq 0.05)$

$\mathrm{CV}=$ coeficient of variation.

\section{CONCLUSIONS}

Considering Cobb $\mathrm{Mx}^{\circledR}$ roosters, it is concluded that: for same age roosters, higher body weight has positive implications in reproductive capacity (greater testes weight and histological characteristics compatible with sperm production); there is regression of the testicles with age advancing and it is more intense in roosters with low body weight; heavier roosters have moderate chance to have higher comb and cloaca scores and also increased amount of foot injuries; in roosters with 45 weeks of age, comb score can be used with moderate potential prediction for selecting roosters with the highest testes weight and characteristics consistent with higher sperm production capacity (tubular diameter and seminiferous epithelium height).

\section{ACKNOWLEDGEMENTS}

To CAPES and CNPq for financial support. To PifPaf $^{\circledR}$ and employees of Sapezal Farm, in particular to Leonardo Eugenio de Araujo Ruiz and Antonio Coelho Queiroz for cooperation and full support in carrying out the experiment. 


\section{REFERENCES}

AMANN, R.P. Lessons for the poultry industry gleaned from experiences with other commodity species. Poult. Sci., v.78, p.419-427, 1999.

ETCHES, R.J. Reproduction in poultry. Wallingford, UK: CAB International, 1996.

FANTINI, M.O.O. Efeitos da redução do peso corporal sobre as características reprodutivas de galos adultos de matriz pesada. 2007. 42f. Tese (Doutorado) - Escola de Veterinária, Universidade Federal de Minas Gerais, Belo Horizonte, MG.

FRAGOSO, J.S; DIAZ, M.P.; MORENO, J.C.A. et al. Relationships between fertility and some parameters in male broiler breeders (body and testicular weight, histology and immunohistochemistry of testes, spermatogenesis and hormonal levels). Reprod. Dom. Anim., v.48, p.345-352, 2013.

FRANÇA, L.R.; GODINHO, C.L. Testis morphometry, seminiferous epithelium cycle length, and daily sperm production in domestic cats (Felis catus). Biol. Reprod., v.68, p.15541561, 2003.

HOCKING, P.M.; BERNARD, R. Effects of male body weight, strain and dietary protein content on fertility and musculo-skeletal disease in naturally mated broiler breeder males. $\mathrm{Br}$. Poult. Sci., v.38, p.29-37, 1997.

KIRBY, J.D.; WASHINGTON, J.; RHOADS, M.L. et al. Impaired testis development and spermatogenesis in adult male fowl following unrestricted prepubertal growth and subsequent growth restriction. Poult. Sci., v.77, Suppl.1, p.91, 1998.

LARA, J.C.L. Reprodução nas aves: desafios do manejo e da nutrição. Rev. Bras. Reprod. Anim., v.39, p.85-90, 2015.
McGARY, S.; ESTEVEZ, I.; BAKST, M.R. et al. Phenotypic traits as reliable indicators of fertility in male broiler breeders, Poult. Sci., v.81, p.102-111, 2002.

NAVARA K.J.; ANDERSON E.M.; EDWARDS M.L. Comb size and color relate to sperm quality: a test of the phenotype-linked fertility hypothesis. Behav. Ecol., v.23, p.1036-1041, 2012.

REZENDE, C.A.; BAIÃO, N.C.; RUIZ, L.E.A.; MARQUES JÚNIOR, A.P. Escores de cloaca e de crista e morfometria testicular em galos de matriz pesada com 71 semanas de idade e três categorias de peso corporal. Arq. Bras. Med. Vet. Zootec., v.66, p.395-404, 2014.

ROSS-AVIAGEN. Manual de manejo de matriz Ross. Campinas: Aviagem, 2013.79p.

SAS user's guide: statistics. Cary: SAS Institute, 2002.

SEXTON, K.J.; RENDEN, J.A.; MARPLE, D.N. et al. Effects of ad libitum and restricted feeding on semen quantity and quality, body composition, and blood chemistry of caged broiler breeder males. Poult. Sci., v.68, p.569$576,1989$.

TYLER, N.C.; GOUS, R.M. The effect of photoperiod on testis weight and comb area of male broiler breeders. Br. Poult. Sci., v.52, p.517-522, 2009.

VIZCARRA, J.A.; KIRBY, J.D.; KREIDER, D.L. Testis development and gonadotropin secretion in broiler breeder males. Poult. Sci., v.89, p.328-334, 2010.

YOUNG, K.A.; BALL, G.F., NELSON, R.J. Photoperiod induced testicular apoptosis in European starlings (Sturnus vulgaris). Biol. Reprod., v.64, p.706-713, 2001. 